\title{
Design and technical aspects of bottom fish trawl (64 m) of Ratnagiri, Maharashtra
}

\author{
NILESH N. SAWANT, ASHISH S. MOHITE AND MAKARAND T. SHARANGDHAR
}

\begin{abstract}
The present study deals with the design and technical aspects of bottom fish trawl (64 m) locally know as 32 Angali disco dol, operated along the Ratnagiri coast of Maharashtra. The material used for the fish trawl is HDPE (High density polyethylene) and the knot type used for construction is a single trawl knot. Blue colour multifilament netting twine was normally used, having twine diameter of $1.25 \mathrm{~mm}$ for construction of netting of wing and square section while $1.00 \mathrm{~mm}$ twine was used for the belly, lengthener and cod end section. The mesh size of the wing and square section was $600 \mathrm{~mm}$ and gradually reduced down to the cod end section $(18 \mathrm{~mm})$. The net was specifically used to catch Ribbonfish, Squid, Croaker, Pomfret etc.
\end{abstract}

KEY WORDS : Trawling, Bottom fish trawl, 32 Angali disco dol

How to cite this Article : Sawant, Nilesh N., Mohite, Ashish S. and Sharangdhar, Makarand T. (2016). Design and technical aspects of bottom fish trawl (64 m) of Ratnagiri, Maharashtra. Engg. \& Tech. in India, 7 (2) : 73-77; DOI : 10.15740/HAS/ETI/7.2/ 73-77. 